\title{
When age matters: boys with Duchenne muscular dystrophy have growth delay and a fat mass accumulation, as they get older
}

Quando a idade importa: meninos com distrofia muscular de Duchenne apresentam atraso no crescimento e acúmulo de massa gorda à medida que envelhecem

Cuando la edad importa: los niños con distrofia muscular de Duchenne tienen un retraso en el crecimiento y una acumulación de masa grasa a medida que envejecen

Received: 05/09/2021 | Reviewed: 05/16/2021 | Accept: 05/18/2021 | Published: 06/06/2021

Thais Alves Cunha

ORCID: https://orcid.org/0000-0002-9932-2338 Federal University of Rio Grande do Norte, Brazil E-mail: thaisalvesc1@gmail.com

Evellyn Câmara Grilo

ORCID: https://orcid.org/0000-0001-7647-6572

Federal University of Rio Grande do Norte, Brazil E-mail: evellyn-cg@ hotmail.com

Ádila Danielly de Souza Costa

ORCID: https://orcid.org/0000-0002-1893-1490

Federal University of Rio Grande do Norte, Brazil E-mail: adilasouza@gmail.com

Karina Marques Vermeulen-Serpa ORCID: https://orcid.org/0000-0003-0021-5741 Federal University of Rio Grande do Norte, Brazil E-mail: karinavermeulen@hotmail.com

Lúcia Leite-Lais

ORCID: https://orcid.org/0000-0002-8061-7048 Federal University of Rio Grande do Norte, Brazil E-mail: lucia.leite@ufrn.br

Mário Emílio Teixeira Dourado-Júnior

ORCID: https://orcid.org/0000-0002-9462-2294

Federal University of Rio Grande do Norte, Brazil E-mail: medourado03@gmail.com José Brandão-Neto

ORCID: https://orcid.org/0000-0003-3414-5171 Federal University of Rio Grande do Norte, Brazil E-mail: brandao-neto@live.com

Sancha Helena de Lima Vale ORCID: https://orcid.org/0000-0002-0972-1678 Federal University of Rio Grande do Norte, Brazil E-mail: sancha.vale@ufrn.br

\begin{abstract}
Anthropometry and body composition evaluation in boys with Duchenne muscular dystrophy (DMD) are challenging, but crucial methods to evaluate the nutritional status, and better anthropometric reference values and body composition predictive equations are needed for this population. Based on these aspects, this study aimed to investigate the hypothesis that changes in anthropometric parameters and body composition of boys with DMD occur according to age. A cross-sectional study with 49 individuals diagnosed with DMD at the neurological outpatient facility at the Onofre Lopes University Hospital in Natal, Brazil, was performed between September 2016 and March 2019. These individuals underwent anthropometric and body composition evaluation. According to age, the participants were divided into four groups: G1 (2.6 - 8.2y), G2 (8.5 - 10.8y), G3 (11.0 - 14.0y), and G4 (15.9 - 23.0y). The parameters weight-for-age (W/A) $(\mathrm{p}=0.025)$, tricipital skinfold (TSF) $(\mathrm{p}=0.027)$, adductor pollicis muscle $(\mathrm{p}=0.041)$, and corrected arm muscle area (cAMA) $(\mathrm{p}=0.005)$ were different among the groups. Regarding anthropometric parameters, was prevalence in the categories of appropriate W/A and a height-for-age (H/A), and eutrophy for body mass index-for-age (BMI/A). For the TSF, there was a higher frequency of severe malnutrition or obesity. The cAMA indicated severe malnutrition in most individuals. As for \%FM, high adiposity was more frequent, increasing over age groups (G1 to G4). The boys with DMD presented different patterns of anthropometric
\end{abstract}


and body composition parameters. An increase of fat mass and a decrease of lean mass with age/disease progression were observed.

Keywords: Anthropometry; Body composition; Muscular dystrophies; Neuromuscular diseases.

\section{Resumo}

A antropometria e a avaliação da composição corporal em meninos com distrofia muscular de Duchenne (DMD) são desafiadoras, porém métodos cruciais para avaliação do estado nutricional, melhores valores de referência antropométrica e equações preditivas de composição corporal necessárias para essa população. Com base nesses aspectos, este estudo teve como objetivo investigar a hipótese de que mudanças nos parâmetros antropométricos e na composição corporal de meninos com DMD ocorrem de acordo com a idade. Um estudo transversal com 49 indivíduos com diagnóstico de DMD do ambulatório de neurologia do Hospital Universitário Onofre Lopes em Natal, Brasil, foi realizado entre setembro de 2016 e março de 2019. Esses indivíduos foram submetidos à avaliação antropométrica e de composição corporal. De acordo com a idade, os participantes foram divididos em quatro grupos: G1 (2,6 - 8,2a), G2 (8,5 - 10,8a), G3 (11,0 - 14,0a) e G4 (15,9 - 23,0a). Os parâmetros peso para idade $(\mathrm{P} / \mathrm{I})(\mathrm{p}=$ 0,025), dobra cutânea tricipital (DCT) $(\mathrm{p}=0,027)$, músculo adutor do polegar $(\mathrm{p}=0,041)$ e área muscular do braço corrigida $(\mathrm{AMBc})(\mathrm{p}=0,005)$ foram diferentes entre os grupos. Em relação aos parâmetros antropométricos, houve prevalência nas categorias de P/I adequado e altura para idade (A/I), e eutrofia para índice de massa corporal para idade (IMC/I). Para o DCT, houve maior frequência de desnutrição grave ou obesidade. O AMBc indicou desnutrição severa na maioria dos indivíduos. Quanto a \%MG, a adiposidade elevada foi mais frequente, aumentando com as faixas etárias (G1 a G4). Os meninos com DMD apresentaram diferentes padrões de parâmetros antropométricos e de composição corporal. Observou-se aumento da massa gorda e diminuição da massa magra com a idade/progressão da doença.

Palavras-chave: Antropometria; Composição corporal; Distrofias musculares; Doenças neuromusculares.

\section{Resumen}

La antropometría y la evaluación de la composición corporal en niños con distrofia muscular de Duchenne (DMD) son métodos desafiantes, pero cruciales para evaluar el estado nutricional, mejores valores de referencia antropométricos y ecuaciones predictivas de la composición corporal necesarias para esta población. A partir de estos aspectos, este estudio tuvo como objetivo investigar la hipótesis de que los cambios en los parámetros antropométricos y la composición corporal de los niños con DMD ocurren según la edad. Entre septiembre de 2016 y marzo de 2019 se llevó a cabo un estudio transversal con 49 individuos diagnosticados de DMD en el ambulatorio de neurología del Hospital Universitário Onofre Lopes en Natal, Brasil. Estos individuos fueron sometidos a evaluación antropométrica y de composición corporal. Según la edad, los participantes se dividieron en cuatro grupos: G1 (2.6 8.2a), G2 (8.5 - 10.8a), G3 (11.0 - 14.0a) y G4 (15, 9 - 23.0a). Los parámetros peso para la edad $(\mathrm{P} / \mathrm{E})(\mathrm{p}=0,025)$, pliegue cutáneo tricipital (PCT) $(\mathrm{p}=0,027)$, músculo aductor del pulgar $(\mathrm{p}=0,041)$ y área corregida del músculo del brazo $(\mathrm{AMBc})(\mathrm{p}=0,005)$ fueron diferentes entre grupos. En cuanto a los parámetros antropométricos, hubo prevalencia en las categorías de P/E adecuado y talla para la edad (T/E), y eutrofia para el índice de masa corporal para la edad (IMC/I). Para PCT, hubo una mayor frecuencia de desnutrición severa u obesidad. AMBc indicó desnutrición severa en la mayoría de las personas. En cuanto al\% MG, la adiposidad alta fue más frecuente, aumentando con los grupos de edad (G1 a G4). Los niños con DMD mostraron diferentes patrones de parámetros antropométricos y composición corporal. Hubo un aumento en la masa grasa y una disminución en la masa magra con la progresión de la edad/enfermedad.

Palabras clave: Antropometría; Composición corporal; Distrofias musculares; Enfermedades neuromusculares.

\section{Introduction}

Dystrophin-associated muscular dystrophies range from the severe Duchenne muscular dystrophy (DMD) to the milder Becker muscular dystrophy (BMD) and are caused by mutations in the gene encoding the dystrophin protein (Xp21; OMIM\#310200) (Shoji et al., 2015). In DMD, there is no dystrophin, or there is insufficient dystrophin production and not functional (Gao \& McNally, 2015). Its absence or deficiency, associated with a concomitant inflammatory response, culminates in exhausting cycles of degeneration and muscle fiber regeneration, resulting in progressive muscle weakness, chronic muscle degeneration, and its replacement by connective and adipose tissue (Cruz-Guzmán, Rodríguez-Cruz, \& Escobar Cedillo, 2015; Davidson \& Truby, 2009).

Nutritional complications are present and get worse with age (Salera et al., 2017). Approximately 75\% of muscle mass loss is expected around ten years of age and loss of independent ambulation around 13 years of age. In order to delay muscle weakness, current drug therapy is based on the use of glucocorticoids (Davis, Samuels, \& Mullins, 2015). Although early 
glucocorticoid therapy leads to significant physical capacity and lung function improvements, side effects such as weight gain and body composition changes require immediate and continuous attention (Davidson \& Truby, 2009).

The body composition of boys with DMD is different from the healthy population. Obesity is expected during childhood, when there is a loss of ambulation due to inactivity, increasing the weight supported by weakened muscles. In the last stages of the disease, usually between adolescence and early adulthood, malnutrition is more recurrent due to impaired food intake. In addition, factors such as growth and maturation affect the levels of fat mass and lean mass.For that reason, anthropometry and body composition evaluation in boys with DMD are challenging but crucial methods to evaluate the nutritional status, to provide adequate and individualized counseling, and to follow the DMD progression (Caromano et al., 2010; Mok et al., 2006, 2010; Rosa, Sales, \& Andrade, 2017).

However, this subject is still lacking in the literature, and better anthropometric reference values and body composition predictive equations are needed for this population. We hypothesize that it is possible to identify the changes in these parameters according to boys get older. Based on these aspects, this study aimed to evaluate boys' anthropometric and body composition parameters with DMD, according to age.

\section{Methodology}

\subsection{Study design}

This is a descriptive and cross-sectional study. A non-probabilistic sample consisted of boys with DMD treated at the neurology outpatient facility of Hospital Universitario Onofre Lopes (HUOL) in Natal/RN, between September 2016 and March 2019. Patients with DMD diagnosis by genetic testing were included. Individuals with other dystrophies $(n=4)$, those unable to have their weight and height, or both, measured or estimated, were excluded as well as symptomatic female carriers of mutations in the DMD gene.

Participants were submitted to anamnesis, anthropometric and body composition assessment. Considering that there is no specific method or classification for this population's anthropometric assessment, the evaluation was based on the age group and reference values for the healthy population. The participants were divided into four groups (Groups 1 to 4) based on percentiles according to the age range. Group 1 (G1) was comprised of participants from 2.6 to 8.2 years old; Group 2 (G2), from 8.5 to 10.8 years old; Group 3 (G3), from 11.0 to 14.0 years old; and Group 4 (G4), from 15.9 to 23.0 years old.

This study was approved by the Ethical Committee in Research (CAAE: 57345516.0.0000.5292, n: 1.754.017). All participants or their guardians provided written consent.

\subsection{Genetic testing}

Saliva or blood samples were used to obtain DNA. The following techniques were used:

(1) Multiplex Ligation-dependent Probe Amplification (MLPA)

Screening with the MLPA analysis test was done to identify precisely which exons are involved in deletions or duplications. Every patient who did not present exon deletions or duplications was pursued molecular investigation through complete gene sequencing. To evaluate the number of copies. The MRCHolland SALSA MLPA P034-B1-1013 and P035-B11013 kits were used. According to the HGVS' recommendations, the notation was done with numbering made from base A of the ATG initiation codon (Lalic et al., 2005; Takeshima et al., 2010).

(2) Gene sequencing

The extracted DNA was subjected to second-generation sequencing on the Illumina platform after enrichment by a capture method. The data were processed for calling variants (SNVs, small indels) and copy number (CNV) analysis for large deletions and exonic duplications in the Genomika-Einstein Pipeline. The expected average coverage was over $99 \%$ of the 
bases with depth over 10x in the exons and 5bp of the adjacent intronic region and other specific non-coding regions known to cause relevant clinical phenotypes at the time of the design of the trial. The variant was numbered using the reference transcript from base A of the ATG initiation codon aligned against the reference genome GRCh37/hg19. According to the American College of Medical Genetics and Genomics' criteria (ACMG), Variants' classification was done. This test detected > 99\% of variants SNVs and small deletions and duplications with up to 20bp. Variants larger than 20bp and smaller than an exon could be detected with reduced sensitivity. Copy number analysis (CNV) for variants of one or more exons had a sensitivity of > 99\%. Variants may not be reported if they are present in gene regions not correctly sequenced, regions rich in repetitions, deep intronic regions, and areas with pseudo-genes (Darras, Urion, \& Ghosh, 2000).

\subsection{Anthropometric and body composition assessment}

Trained nutritionists performed anthropometric and body composition evaluations on all participants. Bodyweight ( $\mathrm{kg}$ ) was measured in a calibrated digital ramp scale with a maximum capacity of $500 \mathrm{~kg}$ (KN P/R 500/50, KN Waagen, São Paulo, Brazil). The height was measured using a stadiometer Sanny® (Professional Sanny, American Medical do Brasil, São Paulo, Brazil). For wheelchair individuals, the height was estimated according to Chumlea et al (Chumlea, Guo, \& Steinbaugh, 1994).

The body mass index (BMI) was calculated as the ratio between body weight and height squared $\left(\mathrm{kg} / \mathrm{m}^{2}\right)$. The values for weight for age (W/A), height-for-age (H/A), and body mass index for age (BMI/A) were calculated using the AnthroPlus v1.0.4 software (available at www.who.int/growthref/en/) and classified according to the World Health Organization (WHO) growth curves for healthy children from 2 to 19 years of age (World Health Organization, 2006) and the Technical Standard of the Food and Nutritional Surveillance System (SISVAN) (Brazil, 2011).

The measurements of the tricipital skinfold (TSF) and the adductor pollicis muscle (APM) were measured using a skinfold caliper (Lange Skinfold Caliper, Beta Technologia Incorporated, Texas, USA) and classified according to the National Center for Health Statistics (NCHS) (1987) (Statistics National Center for Health, 1987). As there are no reference values for the APM measurement, it was only described. The corrected arm muscle area (cAMA) was calculated from the equation by Heymsfield et al. (Heymsfield, McManus, Smith, Stevens, \& Nixon, 1982) and classified in a percentile according to Frisancho (Frisancho, 1990).

The parameters of bioelectrical impedance (BIA), resistance $(\Omega)$ and reactance $(\Omega)$, were obtained using the body composition analyzer (Quantum II, RJL Systems, Michigan, USA). The analyzer promoted the passage of a single safe, painless, and low electrical frequency current $(50 \mathrm{kHz})$. Following BIA's parameters, lean mass $(\mathrm{kg})$ was calculated using the equation proposed by Schaefer et al. (Schaefer, Georgi, Zieger, \& Scharer, 1994). The percentage of fat mass (\% FM) was calculated based on the individual's total weight.

\subsection{Statistical analysis}

Statistical analysis was based on data distribution on a Gaussian curve, using the Shapiro-Wilk test. The data were analyzed using the Intel Statistical Package for the Social Sciences (SPSS) v. $23^{\circledR}$ software (IBM SPSS Statistics for Windows, Version 24.0. Armonk, NY: IBM Corp.). The parametric data were expressed as mean and standard deviation and the nonparametric data as median and confidence interval (95\%). Anthropometric and body composition data were compared between groups using the Analysis of Variance test (ANOVA) and Student's t-test. The descriptive data classifications were presented as absolute numbers and frequency. A significance level of 5\% was adopted for all analyses. 


\section{Results}

Forty-nine individuals diagnosed with DMD, aged between 2.6 and 23.0 years, were enrolled in the study. None of these individuals had acute diseases, $81.6 \%$ used glucocorticoids, and $49.0 \%$ had a loss of independent ambulation.

Regarding the anthropometric evaluation, the following parameters were different among the groups: W/A ( $\mathrm{p}=$ 0.025), TSF ( $\mathrm{p}=0.027)$, APM $(\mathrm{p}=0.041)$, and cAMA $(\mathrm{p}=0.005)$ (Table 1$)$.

Table 1. Anthropometric and body composition characterization of individuals with Duchenne muscular dystrophy.

\begin{tabular}{|c|c|c|c|c|c|}
\hline \multirow[t]{2}{*}{ Variables } & $\begin{array}{c}\text { G1 } \\
(n=13)\end{array}$ & $\begin{array}{c}\text { G2 } \\
(n=12)\end{array}$ & $\begin{array}{c}\text { G3 } \\
(n=12)\end{array}$ & $\begin{array}{c}\text { G4 } \\
(n=12)\end{array}$ & \multirow[t]{2}{*}{$p^{*}$} \\
\hline & \multicolumn{4}{|c|}{ Mean (SD) } & \\
\hline Age $(\text { years })^{\dagger}$ & $5.5(1.8)$ & $9.8(0.7)$ & $12.5(1.1)$ & $19.0(2.0)$ & $<0.001$ \\
\hline Weight $(\mathrm{kg})^{\dagger}$ & $19.6(4.3)$ & $25.6(11.2)$ & $37.6(15.3)$ & $53.1(16.4)$ & $<0.001$ \\
\hline Height $(\mathrm{cm})^{\dagger}$ & $107.4(10.9)$ & $130.1(6.2)$ & $141.7(12.6)$ & $154.3(11.0)$ & $<0.001$ \\
\hline W/A (z-score) $)^{\dagger \dagger}$ & $-0.11(0.88)$ & $0.06(2.36)$ & - & - & $0.025^{\&}$ \\
\hline $\mathrm{H} / \mathrm{A}(\mathrm{z} \text {-score })^{\dagger}$ & $-1.07(1.13)$ & $-1.11(1.09)$ & $-1.55(1.54)$ & $-2.02(1.04)$ & 0.335 \\
\hline BMI/A (z-score) $)^{\dagger}$ & $0.83(0.96)$ & $-0.35(2.50)$ & $0.45(4.92)$ & $0.03(2.14)$ & 0.411 \\
\hline $\mathrm{TSF}(\mathrm{mm})^{\dagger}$ & $6.5(5.5)$ & $8.5(10.5)$ & $15.3(8.9)$ & $18.5(8.9)$ & 0.027 \\
\hline $\operatorname{APM}(\mathrm{mm})^{\dagger}$ & $5.3(1.5)$ & $4.9(2.4)$ & $6.6(2.3)$ & $8.2(4.3)$ & 0.041 \\
\hline cAMA $\left(\mathrm{cm}^{2}\right)^{\dagger}$ & $7.0(2.9)$ & $5.3(7.1)$ & $10.5(7.7)$ & $18.8(20.6)$ & 0.005 \\
\hline $\mathrm{FM}(\%)^{\dagger}$ & $24.1(13.6)$ & $26.8(20.0)$ & $31.9(18.9)$ & $42.3(18.1)$ & 0.093 \\
\hline
\end{tabular}

SD: Standard deviation; W/A: Weight-for-age; H/A: Height-for-age; BMI/A: Body Mass Index-for-age; TS: Triciptal skinfold; APM: Adductor Pollicis Muscle; cAMA: Corrected Arm Muscle Area; FM: Fat Mass.

$\dagger$ Classification for individuals from 2 to 19 years $(n=46) ; \dagger$ Classification for individuals from 2 to 10 years $(n=25)$;

*ANOVA; ${ }^{*}$ Test $t$. The data were described as mean (standard deviation).

Source: Authors.

Regarding the anthropometric parameters' classification, such as W/A, H/A, and BMI/A, most participants from all groups presented age-appropriate weight, height appropriate for age, and eutrophy, respectively (Table 2). However, most participants from G4 had a short H/A (participants with scoliosis and contractures were not considered for this analysis). According to TSF, all groups showed a higher frequency of severe malnutrition or obesity, with a slight reduction of severe malnutrition over the groups G1 to G4, and increased obesity over the groups G1 to G4. Regarding the cAMA, severe malnutrition was found in all individuals (G1) or most of them (G2, G3, G4). Regarding the \%FM, high adiposity was more frequent, and its increase was observed over the age groups (G1 to G4). 
Table 2. Classification of anthropometric and body composition parameters of individuals with Duchenne muscular dystrophy.

\begin{tabular}{|c|c|c|c|c|}
\hline \multirow[t]{2}{*}{ Classifications } & $\begin{array}{l}\text { G1 } \\
(n=13)\end{array}$ & $\begin{array}{l}\text { G2 } \\
(n=12)\end{array}$ & $\begin{array}{l}\text { G3 } \\
(n=12)\end{array}$ & $\begin{array}{l}\text { G4 } \\
(n=12)\end{array}$ \\
\hline & \multicolumn{4}{|c|}{$\%(n)$} \\
\hline \multicolumn{5}{|l|}{ Weight-for-age (z-score) } \\
\hline Very low weight for age & $0.0(0)$ & $0.0(0)$ & & \\
\hline Low weight for age & $0.0(0)$ & $12.5(1)$ & - & - \\
\hline Age-appropriate weight & $100(13)$ & $75.0(6)$ & & \\
\hline High weight for age & $0.0(0)$ & $12.5(1)$ & & \\
\hline \multicolumn{5}{|l|}{ Height-for-age (z-score) } \\
\hline Very short height for age & $0.0(0)$ & $0.0(0)$ & $25.0(3)$ & $0.0(0)$ \\
\hline Short height for age & $23.1(3)$ & $16.7(2)$ & $8.3(1)$ & $66.7(4)$ \\
\hline Height appropriate for age & $76.9(10)$ & $83.3(10)$ & $66.7(8)$ & $33.3(2)$ \\
\hline \multicolumn{5}{|l|}{ BMI-for-age (z-score) } \\
\hline Sharp thinness & $0.0(0)$ & $0.0(0)$ & $25(3)$ & $0.0(0)$ \\
\hline Thinness & $0.0(0)$ & $16.7(2)$ & $0.0(0)$ & $33.3(2)$ \\
\hline Eutrophy & $61.5(8)$ & $50.0(6)$ & $50.0(6)$ & $33.3(4)$ \\
\hline Risk of overweight & $15.4(2)$ & $0.0(0)$ & $0.0(0)$ & $0.0(0)$ \\
\hline Overweight & $7.7(1)$ & $8.3(1)$ & $8,3(1)$ & $17.6(1)$ \\
\hline Obesity & $15.4(2)$ & $8.3(1)$ & $16.7(2)$ & $0.0(0)$ \\
\hline Severe obesity & $0.0(0)$ & $16.7(2)$ & $0.0(0)$ & $16.7(1)$ \\
\hline \multicolumn{5}{|l|}{$\mathrm{TSF}(\mathrm{mm})$} \\
\hline Severe malnutrition & $50.0(6)$ & $50.0(6)$ & $33.3(4)$ & $33.3(4)$ \\
\hline Moderate malnutrition & $16.7(2)$ & $8.3(1)$ & $0.0(0)$ & $0.0(0)$ \\
\hline Mild malnutrition & $8.3(1)$ & $8.3(1)$ & $16.7(2)$ & $8.3(1)$ \\
\hline Eutrophy & $0.0(0)$ & $0.0(0)$ & $8.3(1)$ & $8.3(1)$ \\
\hline Overweight & $8.3(1)$ & $0.0(0)$ & $8.3(1)$ & $8.3(1)$ \\
\hline Obesity & $16.7(2)$ & $33.3(4)$ & $33.3(4)$ & $41.7(5)$ \\
\hline \multicolumn{5}{|l|}{$\mathrm{cAMA}\left(\mathrm{cm}^{2}\right)$} \\
\hline Normal & $0.0(0)$ & $0.0(0)$ & $0.0(0)$ & $8.3(1)$ \\
\hline Mild/moderate malnutrition & $0.0(0)$ & $8.3(1)$ & $8.3(1)$ & $0.0(0)$ \\
\hline Severe malnutrition & $100(12)$ & $91.7(11)$ & $91.7(11)$ & $91.7(11)$ \\
\hline \multicolumn{5}{|l|}{ FM (\%) } \\
\hline Normal & $33.3(2)$ & $33.3(4)$ & $25.0(3)$ & $16.7(2)$ \\
\hline High adiposity & $66.7(4)$ & $66.7(8)$ & $75.0(9)$ & $83.3(10)$ \\
\hline
\end{tabular}

BMI: Body Mass Index; TSF: Triciptal SkinFold; cAMA: Corrected Arm Muscle Area; FM: Fat Mass. Lost data were excluded from the analysis (n) of TSF (1), cAMA (1), W/A (4), H/A (6), BMI/A (6), and FM (7). Source: Authors. 


\section{Discussion}

Nutritional complications are frequently present in individuals with neuromuscular diseases, worsening with advancing age. Therefore, anthropometric and body composition evaluation in individuals with DMD is essential to check their nutritional status through disease progression, guide nutritional intervention, and promote a better quality of life (Salera et al., 2017). Our hypothesis that is identifying the changes in these parameters according to boys get older was partly accepted since the weight-for-age $\mathrm{z}$-score and triciptal skinfold values change significantly according to age.

According to West et al., boys with DMD from the age of five have lower W/A at the 10th percentile than the general male pediatric population (West et al., 2013). In our study, the W/A z-core was higher in G1 than G2 (p = 0.025), demonstrating that the weight changes resulting from the disease may not appear in early childhood. Lamb et al. observed that longer duration and greater cumulative dose of glucocorticoids are significantly associated with lower W/A z-scores (Lamb et al., 2018).

Although there is no difference in H/A z-scores among the groups, it decreases over the age groups (G1 to G4) (Table 1), indicating growth delay with disease progression. According to Caromano et al., adolescents with DMD from 12 years of age start to show growth deficits (Caromano et al., 2010). A similar result was found in a study carried out in Australia, in which the average H/A z-score in boys with DMD was lower compared to the reference for healthy children and adolescents (Elliott, Davidson, Davies, \& Truby, 2015). This fact may indicate linear growth failure due to chronic use of steroids and late puberty or may reflect an inaccurate height measurement since scoliosis and contractures of the limbs may be expected in DMD, especially in nonambulant, and tend to worsen with puberty (Davis et al., 2015; Ishizaki et al., 2017; Joseph et al., 2019).

In this study, a predominance of eutrophy was found in all groups according to BMI/A z-score (Table 2). More significant heterogeneity in the BMI/A classifications is noticed with advancing age (G4). However, it is known that BMI does not differentiate lean and fat mass, and should not be used as an isolated parameter to monitor the nutritional status, especially in individuals with DMD, since the increase of adiposity along the age is a characteristic of this disease, and it is not accurately reflected by this parameter (Skalsky, Han, Abresch, Shin, \& McDonald, 2009).

Concerning TSF, Ishizaki et al. (Ishizaki et al., 2017) concluded that this parameter might be used as a nutritional screening tool for patients with advanced DMD when imaging assessment (computed tomography and magnetic resonance) is difficult or unavailable. In our study, mean TSF values were different among all groups (Table 1). Also, we observed a higher prevalence of severe malnutrition in the early stages of the disease and increased adiposity in the latter groups (Table 2). These results emphasize the accumulation of adipose tissue resulting from the disease, but it does not reflect the muscle fatty infiltration characteristic in these boys (Bayram et al., 2013).

The APM is a flat muscle fixed between two bone structures that can be measured directly and undergoes minimal subcutaneous fat interference. Furthermore, APM is correlated to parameters of nutritional status and muscle mass (Pereira, Neves, Bastos, \& Cândido, 2018). In our study, APM had a significant increase along with the groups (Table 1), indicating either infiltration of muscle fat or muscle development concerning age. The APM classification was absent because of the lack of adequate reference.

The cAMA is a useful parameter for evaluating DMD patients since it estimates the maximum voluntary strength of the upper limbs and trunk and reflects the lean mass (Pontes, Ferreira, Fregonezi, Sena-Evangelista, \& Dourado Junior, 2012; Serpa, Nogueira, \& Pompeu, 2014). In our study, this parameter detected a high prevalence of severe malnutrition in all groups (Table 2). Similarly, Hogan et al. (Hogan, 2008) found that patients with DMD had reduced cAMA compared to healthy peers. The loss of lean mass through cAMA occurs concomitant with an increase in fat mass, indicated by the TSF. 
Regarding the \%FM, a significant prevalence of high adiposity was found in all groups with increased fat mass with age. Likewise, Bernabe-García et al. (Bernabe-García et al., 2019) found that as age advances, the fat mass increases while lean mass decreases. Besides, Caromano et al. (Caromano et al., 2010) noticed that body fat accumulation is also influenced by a sedentary lifestyle and may not reflect weight change due to loss of lean mass. The intense muscular atrophy causes this loss as a consequence of the disease (Vermeulen et al., 2019).

BIA is a non-invasive test, easy to perform, low-cost, and sensitive to fat mass changes (Barja, 2016). The predictive equations for BIA validated for the healthy population should be applied with caution in patients with DMD since their body composition is affected by the disease, sedentary lifestyle, and the prolonged use of steroids (Elliott et al., 2015). However, Grilo et al. (Grilo et al., 2020) aimed to validate the BIA method using predictive formulas compared to dual-energy X-ray absorptiometry imaging, concluding that BIA is a viable method for estimating the percentage of fat-free mass in children and adolescents with DMD.

This study had limitations, mainly about the difficulty of establishing comparisons with other populations, healthy or not, with this same characteristic of the body composition in the DMD, since there are no validated tools for this evaluation. Another limitation is the fact that it does not certify that in group G1, there are no boys with the mildest form of the disease (Becker).

\section{Conclusion}

The boys with DMD presented different patterns of anthropometric and body composition parameters. An increase of fat mass and a decrease of lean mass with age/disease progression were observed. These parameters must be monitored in patients with DMD as part of the nutrition care process since it will contribute to disease management and quality of life. Further studies are needed to develop reference values for anthropometry and body composition in this population.

\section{Acknowledgments}

Special thanks to the research participants and their families.

\section{Financial support}

This study was supported by the National Council for Scientific and Technological Development (CNPq), grant number 422667/2016-1, 302298/2017-7 and 132885/2020-4.

\section{Conflicts of interest}

The authors declare no conflicts of interest.

\section{References}

Barja, S. (2016). Clinical Nutrition ESPEN Clinical assessment underestimates fat mass and overestimates resting energy expenditure in children with neuromuscular diseases, $15,11-15$.

Bayram, E., Topcu, Y., Karakaya, P., Bayram, M. T., Sahin, E., Gunduz, N., Yis, U., et al. (2013). Correlation between motor performance scales, body composition, and anthropometry in patients with duchenne muscular dystrophy. Acta Neurologica Belgica, $113(2), 133-137$.

Bernabe-García, M., Rodríguez-Cruz, M., Atilano, S., Cruz-Guzmán, O. del R., Almeida-Becerril, T., Calder, P. C., \& González, J. (2019). Body composition and body mass index in Duchenne muscular dystrophy: Role of dietary intake. Muscle and Nerve, 59(3), $295-302$. 
na distrofia muscular de Duchenne. Fisioterapia em movimento (Impresso), 23(2), 221-227.

Chumlea, W. M. C., Guo, S. S., \& Steinbaugh, M. L. (1994). Prediction of stature from knee height for black and white adults and children with application to mobility impaired or handicapped persons. J. Am. Diet. Assoc., 94, 1385-8.

Cruz-Guzmán, O. D. R., Rodríguez-Cruz, M., \& Escobar Cedillo, R. E. (2015). Systemic inflammation in duchenne muscular dystrophy: Association with muscle function and nutritional status. BioMed Research International, 7.

Darras, B. T., Urion, D. K., \& Ghosh, P. S. (2000). Dystrophinopathies. (M. Adam, H. Ardinger, \& R. Pagon, Eds.). Seattle: GeneReviews. ttps://www.ncbi.nlm.nih.gov/books/NBK1119/pdf/Bookshelf_NBK1119.pdf

Davidson, Z. E., \& Truby, H. (2009). A review of nutrition in Duchenne muscular dystrophy. Journal of Human Nutrition and Dietetics, $22(5), 383-393$.

Davis, J., Samuels, E., \& Mullins, L. (2015). Nutrition Considerations in Duchenne Muscular Dystrophy. Nutrition in Clinical Practice, $30(4), 511-521$.

Elliott, S. A., Davidson, Z. E., Davies, P. S. W., \& Truby, H. (2015). Pediatric Neurology A Bedside Measure of Body Composition in Duchenne Muscular Dystrophy. Pediatric Neurology, 52(1), 82-87. Elsevier Inc.

Frisancho, A. R. (1990). Anthropometric Standards for the assessment of growth and nutritional status. University of Michigan Press, 189.

Gao, Q., \& McNally, E. M. (2015). The Dystrophin Complex: structure, function and implications for therapy. Compr Physiol, 5(3), $1223-1239$.

Grilo, E. C., Cunha, T. A., Costa, Á. D. S., Araújo, B. G. M., Lopes, M. M. G. D., Maciel, B. L. L., Alves, C. X., et al. (2020). Validity of bioelectrical impedance to estimate fat-free mass in boys with Duchenne muscular dystrophy. PLoS ONE, 15(11 November), 1-12.

Heymsfield, S. B., McManus, C., Smith, J., Stevens, V., \& Nixon, D. W. (1982). Anthropometric measurement of muscle mass: Revised equations for calculating bone-free arm muscle area. American Journal of Clinical Nutrition, 36(4), 680-690.

Hogan, S. E. (2008). Body Composition and Resting Energy Expenditure of Individuals With Duchenne and Becker Muscular Dystrophy. Canadian Journal of Dietetic Practice and Research, 69(4).

Ishizaki, M., Kedoin, C., Ueyama, H., Maeda, Y., Yamashita, S., \& Ando, Y. (2017). Utility of skinfold thickness measurement in non-ambulatory patients with Duchenne muscular dystrophy. Neuromuscular Disorders, 27(1), 24-28. Elsevier B.V.

Joseph, S., Wang, C., Bushby, K., Guglier, M., Horrocks, I., Straub, V., Ahmed, S. F., et al. (2019). Fractures and Linear Growth in a Nationwide Cohort of Boys With Duchenne Muscular Dystrophy With and Without Glucocorticoid Treatment: Results From the UK NorthStar Database. JAMA Neurol.

Lalic, T., Vossen, R. H. A. M., Coffa, J., Schouten, J. P., Guc-Scekic, M., Radivojevic, D., Djurisic, M., et al. (2005). Deletion and duplication screening in the DMD gene using MLPA. European Journal of Human Genetics, 13(11), 1231-1234.

Lamb, M. M., Cai, B., Royer, J., Pandya, S., Soim, A., Valdez, R., Diguiseppi, C., et al. (2018). The effect of steroid treatment on weight in nonambulatory males with Duchenne muscular dystrophy. Wiley Periodicals, (July), 1-9.

Mok, E., Béghin, L., Gachon, P., Daubrosse, C., Fontan, J.-E., Cuisset, J.-M., Gottrand, F., et al. (2006). Estimating body composition in children with Duchenne muscular dystrophy: comparison of bioelectrical impedance analysis and skinfold-thickness measurement. The American journal of clinical nutrition, 83(1), 65-69.

Mok, E., Letellier, G., Cuisset, J. M., Denjean, A., Gottrand, F., \& Hankard, R. (2010). Assessing change in body composition in children with Duchenne muscular dystrophy: Anthropometry and bioelectrical impedance analysis versus dual-energy X-ray absorptiometry. Clinical Nutrition, 29(5), 633-638. Elsevier Ltd.

Pereira, P. M. de L., Neves, F. S., Bastos, M. G., \& Cândido, A. P. C. (2018). Adductor Pollicis Muscle Thickness for nutritional assessment : a systematic review. Rev. Bras. Enferm., 71(6), 3093-3102.

Pontes, J. F., Ferreira, G. M. H., Fregonezi, G., Sena-Evangelista, K. C. M. de, \& Dourado Junior, M. E. (2012). Força muscular respiratória e perfil postural e nutricional em crianças com doenças neuromusculares. Fisioterapia em Movimento, 25(2), 253-261.

Rosa, V. S., Sales, C. M. M., \& Andrade, M. A. C. (2017). Acompanhamento nutricional por meio da avaliação antropométrica de crianças e adolescentes em uma unidade básica de saúde. Rev. Bras. Pesq. Saúde, 19, 28-33.

Salera, S., Menni, F., Moggio, M., Guez, S., Sciacco, M., \& Esposito, S. (2017). Nutritional challenges in duchenne muscular dystrophy. Nutrients, 9(6), 1-10.

Schaefer, F., Georgi, M., Zieger, A., \& Scharer, K. (1994). Usefulness of Bioelectric Impedance and Skinfold Measurements in Predicting Fat-Free Mass Derived from Total Body Potassium in Children. Pediatric Research, 35(5).

Serpa, T. K. F., Nogueira, F. dos S., \& Pompeu, F. A. M. S. (2014). Predição da massa corporal magra de adultos brasileiros através da área muscular do braço. Revista Brasileira de Medicina do Esporte, 20(3), 186-189.

Shoji, E., Sakurai, H., Nishino, T., Nakahata, T., Heike, T., Awaya, T., Fujii, N., et al. (2015). Early pathogenesis of Duchenne muscular dystrophy modelled in patient-derived human induced pluripotent stem cells. Scientific Reports, 5(August), 1-13. Nature Publishing Group.

Skalsky, A. J., Han, J. J., Abresch, R. T., Shin, C. S., \& McDonald, C. M. (2009). Assessment of regional body composition with dual-energy X-ray absorptiometry in Duchenne muscular dystrophy: Correlation of regional lean mass and quantitative strength. Muscle and Nerve, 39(5), 647-651.

Statistics National Center for Health. (1987). Anthropometric Reference Data and Prevalence of Overweight United National Center for Health Statistics. Hyattsville, Md. 
Research, Society and Development, v. 10, n. 6, e44010615922, 2021

(CC BY 4.0) | ISSN 2525-3409 | DOI: http://dx.doi.org/10.33448/rsd-v10i6.15922

Takeshima, Y., Yagi, M., Okizuka, Y., Awano, H., Zhang, Z., Yamauchi, Y., Nishio, H., et al. (2010). Mutation spectrum of the dystrophin gene in 442 Duchenne/Becker muscular dystrophy cases from one Japanese referral center. Journal of Human Genetics, 55(6), 379-388. Nature Publishing Group. Retrieved from http://dx.doi.org/10.1038/jhg.2010.49

Vermeulen, K. M., Lopes, M. M. G. D., Grilo, E. C., Alves, C. X., Machado, R. J. A., Lais, L. L., Brandão-neto, J., et al. (2019). Bioelectrical impedance vector analysis and phase angle in boys with Duchenne muscular dystrophy, 1, 1-9.

West, N. A., Yang, M. L., Weitzenkamp, D. A., Andrews, J., Meaney, F. J., Oleszek, J., Miller, L. A., et al. (2013). Patterns of Growth in Ambulatory Males with Duchenne Muscular Dystrophy. The Journal of Pediatrics, 163(6), 1759-1763.e1. Elsevier Ltd.

World Health Organization. (2006). WHO Child Growth Standards: Length/height-for-age, weight-for-age, weight-forlength, weight-for-height and body mass index-for-age. Retrieved from https://www.who.int/childgrowth/standards/technical_report/en/ 